\title{
Diseases in North Sea fishes
}

\author{
V. Dethlefsen
Bundesforschungsanstalt für Fischerei, Institut für Küsten- und Binnenfischerei, Toxikologisches Laboratorium Cuxhaven; Niedersachsenstraße, D-2190 Cuxhaven, Federal Republic of Germany

\begin{abstract}
Prior to the studies reviewed here, only lymphocystis and skeletal deformities of a variety of fish species and certain diseases of eel were known to occur in the German Bight (North Sea). From 1977 until now, 9 externally visible lesions on North Sea fishes were observed; in addition to those mentioned before, they comprise: fin rot, ulcerations, epidermal papilloma, hyperplasia, pseudobranchial tumour, eye diseases and gill swellings. With the exception of information on changes in frequencies of vertebral deformities of herring from the 1950's to the 1970 's, there are no long-term data characterizing changes in frequencies of the diseases under study. For pseudobranchial tumours of cod and epidermal papilloma of dab, information is provided on occurrence and abundance. The distribution pattern of cod afflicted with pseudobranchial tumours is strongly influenced by the migratory behaviour of the fish. Epidermal papillomas of dab were more frequently found at stations within the inner German Bight than in neighbouring areas. The Bight is used for dumping of wastes from titaniumdioxide production. Further disease hot spots are areas off the Humber estuary and the British coast. Analysis of chromium in dab from the German Bight revealed elevated concentrations in epidermal tissues of specimens from the dumping area compared with that found in dab from neighbouring localities. Particulate iron was demonstrated to occur in mucous cells of dab from the dumping area. From increased levels of heavy metals with cancerogenic potential in sensitive target tissues and from increased prevalences of diseased fish in the dumping area it is concluded that these phenomena are possibly causally linked. In the vicinity of the Humber estuary high disease rates were encountered and areas with high prevalences of dab afflicted with epidermal papilloma extended over regions shown to be transport routes for persistent pollutants such as radioactive materials. It is therefore suggested that the long-range distribution of fish diseases in the southern North Sea might reflect the long-range transport of persistent pollutants.
\end{abstract}

\section{INTRODUCTION}

Diseases of marine fishes have received considerable attention during the last few years. This is partly due to the fact that monitoring of diseases of marine fishes has been recommended as a useful tool for biological effects monitoring (McIntyre \& Pearce, 1980). External diseases of marine fishes were recognized as having a potential for biological effects monitoring, among them fin rot, ulcerations, epidermal papillomas and skeletal deformities (Sindermann et al., 1980). With increasing interest in occurrence and abundance of the diseases of marine fishes a scientific debate developed on the question whether some diseases of marine fishes might be caused by pollution or not. Sindermann $(1979,1983)$ has provided the most comprehensive reviews on this subject. His basic assumption is that in animals responding to stress, many responses may result in a departure from normal structure or function (Sindermann, 1983). Much of the 
confusion in the present debate on the possible contribution of water pollution to increased prevalences of diseases of marine organisms is due to the fact that the broadness of this concept has not sufficiently been taken into account.

Whenever correlations were found between hydrographic or biotic factors and the prevalence of disease, pollution was readily rejected as a potential cause (Shelton \& Wilson, 1973; Möller, 1979, 1981). One of the prerequisites for assessing the disease status of marine organisms are sound baseline data, including information on seasonal and geographical variation in the occurrence of the phenomena involved. This paper reviews results obtained in a 5-yr study on occurrence and abundance of external lesions, diseases, and anomalies of North Sea fishes. During these investigations (Dethlefsen, 1980; Dethlefsen \& Watermann, 1980; Watermann et al., 1982) cod and dab turned out to be most frequently afflicted with a variety of externally visible disease phenomena. For this reason, most information considered here concentrates on these two species. A more comprehensive review will be published elsewhere (Dethlefsen, Watermann \& Hoppenheit, in prep.).

\section{STATUS OF FISH DISEASES IN THE NORTH SEA}

The occurrence of diseased fishes in the North Sea is not a new phenomenon. Johnstone $(1913,1925)$ provided a wealth of information on diseases of North Sea fishes. Unfortunately, no quantitative information is given on the frequency of the diseases described and the question has to be left open whether or not they were occurring only singularly. Systematic fish-disease surveys in the German Bight, which were later extended to the whole of the North Sea, were not conducted prior to 1977. In the German Bight, lymphocystis in fishes has been known to exist since the turn of the century (Schäperclaus, 1979). More recent findings on flatfish in the German Bight have been reported by Mann (1970). A variety of skeletal deformities on a number of fish species was described by Wunder (1971). Certain diseases of eel - red disease and cauliflower disease - were known to occur since the 1950's in remarkable frequencies (Koops \& Mann, 1969; Koops et al., 1970; Peters et al., 1972; Peters, 1975). Ulcerations on flatfish were first reported by Bückmann (1952) from onshore waters although in the personal files of Jas. Johnstone much earlier descriptions of this disease are found (David Bucke, Weymouth, pers. comm.).

During 11 cruises between 1948 and 1955, conducted by personnel of the Biologische Anstalt Helgoland in the German Bight, two disease phenomena were found: lymphocystis in dab and plaice, and skeletal deformities in cod and whiting (Table 1). Only lymphocystis and skeletal deformities had been described in fishes of the German Bight in the earlier literature. Since the 1950's, red disease and cauliflower disease on eel, and ulcerations on plaice were reported. In our studies, conducted since 1977. we discovered many more diseases in fishes of the German Bight: fin rot, epidermal papillomas, pseudobranchial tumours, hyperplasia, inflammation of the eye, and gill swellings (Table 1).

Lymphocystis, ulcerations, fin rot and skeletal deformities were found in more than one fish species. Most widespread were ulcers on 15 different fish species encountered during our investigations from May 1980 to January 1982 during 10 cruises, performing a total of 399 trawl catches (Table 2). 
Table 1. Diseases of fishes in the southern North Sea. Comparison between diseases mentioned in early literature (Schäperclaus, 1979), those found during routine fisheries investigations between 1948 and 1955 (11 cruises) carried out in coastal areas of the German Bight (unpubl. data of A. Kotthaus, Biologische Anstalt Helgoland), and those found in own surveys

\begin{tabular}{|c|c|}
\hline (I) & $\begin{array}{l}\text { Diseases mentioned in early literature } \\
\text { Lymphocystis (many species) } \\
\text { Cauliflower (eel) } \\
\text { Red disease (eel) } \\
\text { Skeletal deformities (many species) }\end{array}$ \\
\hline (II) & $\begin{array}{l}\text { Diseases recorded between } 1948 \text { and } 1955 \\
\text { Lymphocystis (dab, plaice) } \\
\text { Skeletal deformities (cod, whiting) }\end{array}$ \\
\hline (III) & $\begin{array}{l}\text { Diseases recorded in present surveys } \\
\text { Lymphocystis (dab, flounder, plaice, long rough dab, gurnard) } \\
\text { Cauliflower (eel) } \\
\text { Red disease (eel) } \\
\text { Skeletal deformities (13 species) } \\
\text { Fin rot (8 species) } \\
\text { Ulcerations (15 species) } \\
\text { Hyperplasia/epidermal papilloma (dab) } \\
\text { Hyperplasia (long rough dab, whiting, cod, haddock) } \\
\text { Pseudobranchial tumours (cod) } \\
\text { Inflammation of eye (gadoids and clupeids) } \\
\text { Gill swellings (dab) }\end{array}$ \\
\hline
\end{tabular}

At present, almost nothing is known about long-term changes in the frequency of fish diseases in the North Sea. Only two sets of data date back to the 1950's: (1) for papillomatosis of eel (Peters et al., 1972), and (2) for vertebral deformities of herring (van de Kamp, 1977). In both cases, an increase in frequencies occurred over the period of investigation. When changes in frequencies of vertebral deformities of herring from different areas of the North Atlantic were compared it became clear that significant increases were restricted to east Scottish waters, the central North Sea, and most significantly, the southern North Sea. On the basis of presently available material it is not possible to state with certainty whether frequencies of diseases of marine fishes in the southern North Sea have generally increased in terms of their prevalence. With the exception of pseudobranchial tumour, fin rot, gill abnormalities and hyperplasia, many diseases presently encountered were already mentioned in early reports.

Yet the data available on frequencies of vertebral deformities in herring do not date back far enough to allow conclusions on long-term changes. Periodicities in production cycles in the North Sea can cover periods of more than 40 years (Russel, 1973). Such long-term cycles can affect the significance of increases in frequencies of anomalies in North Sea fishes over shorter periods. A basic requirement for using diseases of marine organisms as a criterion for assessing water quality - changes in prevalences as a function of time - is therefore lacking in the area under consideration.

In the absence of long-term data, regional comparisons are often used to identify pollution hot spots. In the following, information will be given on occurrence and abundance of cod afflicted with pseudobranchial tumours and dab afflicted with epider- 
Table 2. Fish species with lymphocystis, ulcerations, skeletal deformities, and fin rot encountered in the southern North Sea from May 1980 to January 1982. Summary of results from 10 cruises with 399 trawl catches

\begin{tabular}{|c|c|c|c|c|c|}
\hline Species & $\begin{array}{l}\text { Lympho- } \\
\text { cystis }\end{array}$ & Ulcerations & $\begin{array}{l}\text { Hyper- } \\
\text { plasia }\end{array}$ & $\begin{array}{c}\text { Skeletal } \\
\text { deformities }\end{array}$ & Fin rot \\
\hline Limanda Iimanda & $x$ & $x$ & $x$ & $\times$ & $x$ \\
\hline Pleuronectes platessa & $\times$ & $x$ & & $\times$ & $x$ \\
\hline Platichthys flesus & $x$ & $x$ & & $x$ & $x$ \\
\hline Solea solea & & & & & $x$ \\
\hline Hippoglossoides platessoides & $x$ & $x$ & $x$ & & \\
\hline Microstomus kitt & & $x$ & & & \\
\hline Gadus morhua & & $\times$ & $x$ & $x$ & $x$ \\
\hline Merlangius merlangus & & $x$ & $x$ & $x$ & $x$ \\
\hline Melanogrammus aeglefinus & & $x$ & & $x$ & $x$ \\
\hline Clupea harengus & & $x$ & & $x$ & \\
\hline Myxocepalus scorpius & & & & & $x$ \\
\hline Sprattus sprattus & & & & $x$ & \\
\hline Anguilla anguilla & & $x$ & & & \\
\hline Chelidonichthys gurnadus & $\times$ & & & $x$ & \\
\hline Chelidonichthys lucerna & & & & $x$ & \\
\hline Hyperoplus lanceolatus & & $x$ & & & \\
\hline Trachurus trachurus & & $x$ & & & \\
\hline Scomber scombrus & & & & $x$ & \\
\hline Pollachius virens & & $x$ & & $x$ & \\
\hline Enchelyopus cimbrius & & $x$ & & & \\
\hline \multicolumn{6}{|l|}{ Squalus acanthias } \\
\hline Onos tricirratus & & & & $\times$ & \\
\hline
\end{tabular}

mal papillomas, in order to highlight the type of results presently available on the distribution of these phenomena in the area under survey.

\section{MAJOR DISEASES OF COD AND DAB}

\section{Pseudobranchial tumours of cod}

Pseudobranchial tumours in cod Gadus morhua were first detected in the North Sea in 1979 (Dethlefsen, 1980; Watermann et al., 1982). In some cases, symptoms of the disease can be seen externally at the upper edge of the operculum, but mostly they can only be detected after inspecting the buccal cavity or the gill chamber. The condition has been described by Peyron \& Thomas (1929) to occur in cod along the French coast, and reports are available for its occurrence in Norwegian waters (Lange, 1973; Lange \& Johannessen, 1977) and Atlantic waters (Morrison et al., 1979) as well as from the Barent Sea (Egidius et al,, 1981). Early tumour stages appear on the pseudobranchial organ as slight swellings. Later stages reach sizes of some $\mathrm{cm}$ and occur either bilaterally or, less frequently, unilaterally. Histologically, the main characteristic of the tumours is the presence of X-cells. Details of X-cells, occurrence of multinucleated stages, and characteristics of mitosis lead to the assumption that the agents responsible are amoeba (Watermann \& Dethlefsen, 1982). Further work is under way to examine this hypothesis. 
Highest prevalences of this disease were found at stations in the centre of the German Bight. In January 1980, mean infestation rate in this area was $1.9 \%$, in June $19803.1 \%$. In areas outside the central German Bight respective rates of infestation were $0.3 \%$ and $0.6 \%$. Infestation rates were highest in specimens of year classes I and II. When distribution patterns in winter were compared with those in spring, it became evident that the prevalence of the disease was determined by the migratory behaviour of the cod (Lamp, 1973). In January the disease was restricted to the centre, whilst in spring it spread over the whole German Bight. There was also a positive correlation with population density which lead to the assumption that pseudobranchial tumours are an infectious disease. Transmission of communicable diseases is favoured by high population density (Munro, 1983). Pseudobranchial tumours are suspected to induce mortalities in host fishes (Stich et al., 1976; McCain et al., 1979). High prevalences of this disease in young cod and its steep decrease in older ones also indicate that the disease may be lethal.

\section{Epidermal papilloma of dab}

The first description of epidermal papilloma in dab Limanda limanda goes back to Johnstone (1925). He investigated several dab caught in the North Sea without giving details on the location of the catch, or the prevalence of the disease in the dab population concerned. Johnstone provided figures on external appearance of the epithelioma on dab which resemble the most severe cases encountered in present studies. In 1978 this disease was first found in dab of the German Bight (Dethlefsen, 1980). Histological comparison leaves little doubt that the symptoms are identical to those described by Johnstone. Papilloma develop to 5 to $30 \mathrm{~mm}$, and sometimes becomes even larger. They can be found on all epidermal regions, more frequently on body surfaces than on fins. Three histologically different phenomena were encountered during our investigations: (1) Hyperplasia consisting of 10 to 15 cellular layers above the basal membrane. The structure is dedifferentiated and polygonal malphegian cells predominate. (2) Epidermal papilloma were characterized by the presence of stroma which protrude into the epidermal part of the tumours (Watermann, 1979). (3) A macroscopically similar, but histologically different, lesion has been described for dab (Watermann, 1982), occurring mainly on fins and containing cells with typical X-cell features. In the following, the term "epidermal papilloma" is understood to include hyperplasia but not "X-celllesions".

\section{Regional distribution}

Information on the regional distribution of dab afflicted with epidermal papilloma and hyperplasia was given by Dethlefsen \& Watermann (1980). Based on material from 7 cruises it was concluded that the central part of the German Bight and its immediate vicinity was characterized by higher percentages of dab with epidermal papilloma and related lesions than the regions outside of this area. Since no statistical treatment of the data has been attempted and lengths of individuals have not been taken into account as a possible interfering variable, the force of this statement has been doubted (Möller, 1981). In the further process of evaluating the data, use was made of the control chart developed for industrial quality control in order to locate areas of higher prevalence of disease (Watermann et al., 1982). In this approach a weighted mean of the relative 
frequency of diseased fishes for the whole area under observation was taken as the central line in the control chart regarding only those length classes that were found to be afflicted. Positive or negative deviations of the weighted means of the single trawl catches expressed in standard deviation units (Duncan, 1974, p. $403 \mathrm{ff}$.) were taken to differentiate between areas with higher and lower relative frequencies of diseased specimens. For example, stations outside the 1-sigma limit were marked by a +1 or -1 sign, respectively. When stations were found to fall outside the upper 2-sigma limit, they received a $2+$ sign. Boundary lines between sites of higher and lower prevalences of lesions were drawn regarding the signs of stations located within the 1 -sigma limits. Areas were compared by analysis of a series of $2 \times 2$ tables (Cochran, 1954) taking length as an interfering variable. Two typical examples are given for the distribution of epidermal papilloma in winter (January 1980) and summer (June 1980).

\section{German Bight}

J a n u ry 1980 (Fig. 1). Length classes found to be afflicted were 10,16, 18 to 28 , $30 \mathrm{~cm}$ (standard length, $\mathrm{cm}$ below). Total number of specimens caught in afflicted length classes was 2739 and total number of specimens afflicted was 69. Fishes from the Area A in the surroundings of the titaniumdioxide wastes dumping area were afflicted at a rate

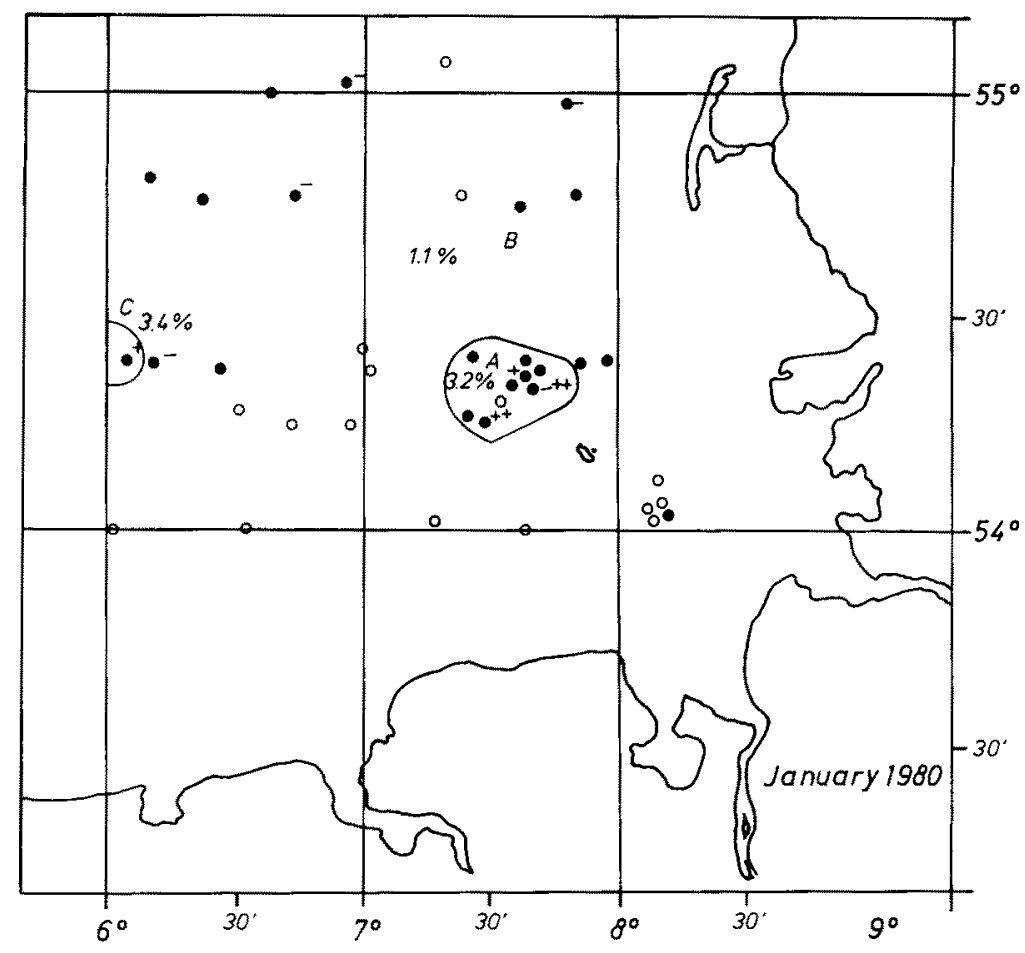

Fig. 1. Limanda limanda: January 1980. Areas of higher (A and C) and lower (B) prevalence of epidermal papilloma. + stations outside the 1 sigma limit $++\infty$ stations outside the upper 2 sigma limit; $O$ stations where $\leqslant 14$ dab were caught (not considered in analysis) 
of $3.2 \%$, while fishes in Area B showed infection rates of $1.1 \%$. Statistical comparison with the infection rate of dab from the reference area yielded no significant difference $(\alpha>0.05)$ (percentages refer only to afflicted length classes).

J u ne 1980 (Fig. 2). Length classes found to be afflicted were 13 to 29 and $34 \mathrm{~cm}$. Total number of specimens caught in afflicted length classes was 20136 , total number of afflicted specimens was 208 . Three areas $-\mathrm{A}, \mathrm{B}$ and $\mathrm{C}-$ with prevalences of $1.7,3.8$ and $0.7 \%$ could be separated by means of the p-chart (percentages refer to afflicted length classes). Figure 3 shows the prevalence as a function of size. Size class $34 \mathrm{~cm}$ was omitted from the graph because only 2 specimens of this size were caught. The

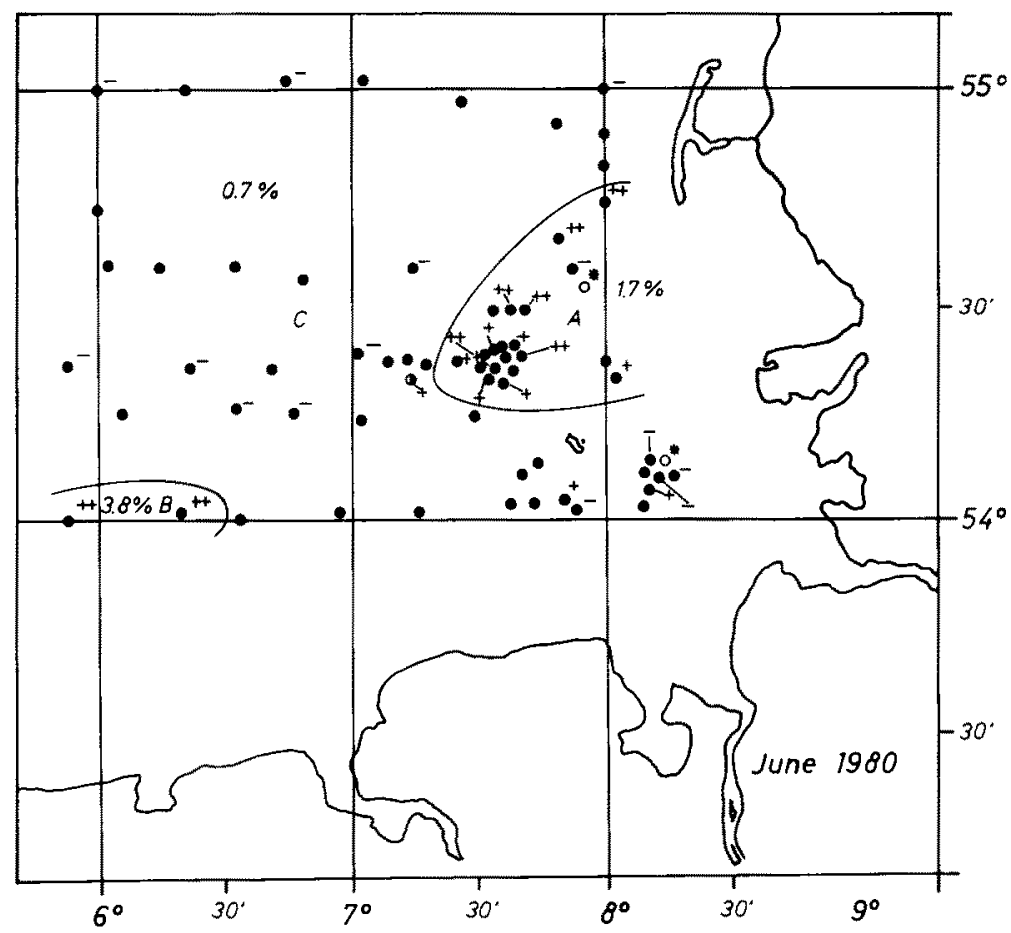

Fig. 2. Limanda limanda: June 1980. Epidermal papilloma (German Bight). For explanation of symbols see Figure 1. Additional symbols: D stations with low number of dab (disregarded in drawing boundary lines but taken into account for calculation of significance). Open circles marked by an asterisk: stations omitted from consideration because length was not measured in all fishes caught

differences in infection rates between Area $\mathrm{C}$ and Areas $\mathrm{A}$ and $\mathrm{B}$ were significant at a level of $\alpha<5 \times 10^{-5}$. Relative frequencies of dab in length classes found to be afflicted in Areas $A$ and $C$ are given in Figure 4. Comparison of length groups 13 to $19 \mathrm{~cm}$, and 20 to $29 \mathrm{~cm}$ yielded significance levels of $\alpha<0.0005$ and $\alpha<0.00025$ respectively. The relative frequencies for length classes 13 to $29 \mathrm{~cm}$ for Areas B and C are given in Figure 5. The significance of the overall difference in prevalences between these two areas is solely based on differences in length classes 21 to $29 \mathrm{~cm}\left(\alpha<5 \times 10^{-5}\right)$. 


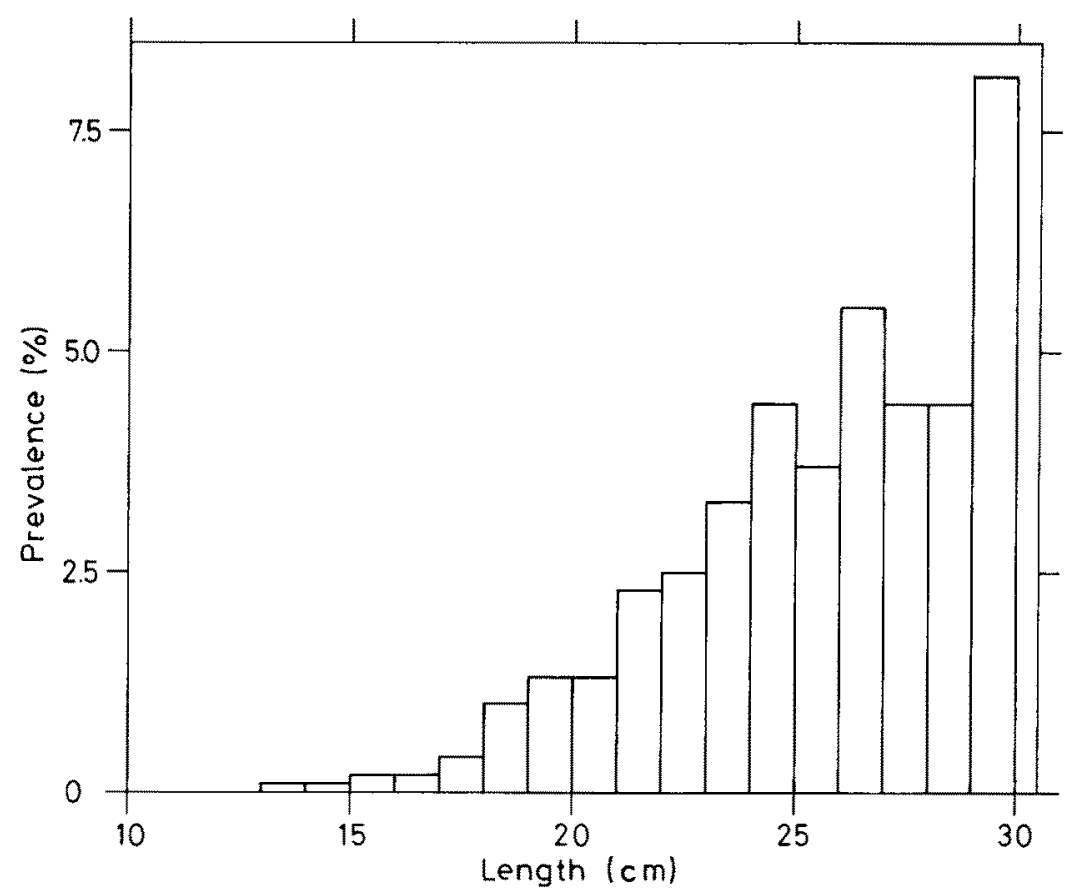

Fig. 3. Limanda limanda: June 1980. Epidermal papilloma. Relative frequency of dab afflicted by epidermal papilloma in relation to length $(n=20134)$

Increased prevalences of tumour-bearing dab can be demonstrated to occur in the dumping area for wastes from titandioxide production. For the example chosen (June 1980), fishes of both length groups contribute to the significance of difference in prevalences between the dumping area and comparison area. When prevalences from Areas $\mathrm{B}$ and $\mathrm{C}$ are compared it becomes obvious that the difference is caused only by fishes of larger size.

To characterize the occurrence and abundance of this disease outside the German Bight area, i.e. in the North Sea, two examples are given, for January 1983 and June 1982.

\section{North Sea}

Ja $\mathrm{n}$ u a ry 1983 . The total number of dab investigated was 7280 ; the number of fish afflicted $123=1.7 \%$ (Fig. 6) (percentage refers to total number investigated). Stations within the German Bight and on a northwestern transect up to $56^{\circ} \mathrm{N}$ showed high percentages of afflicted fish. At stations off the Humber estuary, similarly high percentages of afflicted specimens were caught. Highest percentages of infections were found at 2 stations on a northeastern transect off the Humber estuary.

$\mathrm{J}$ u n e 1982 . The total number of dab investigated was $22794 ; 340$ specimens were afflicted $=1.5 \%$ (Fig. 7) (percentage refers to total number investigated). In the northern and central northern part of the area investigated only low numbers of dab were caught. No diseased specimens were amongst these. Increased relative frequencies of 


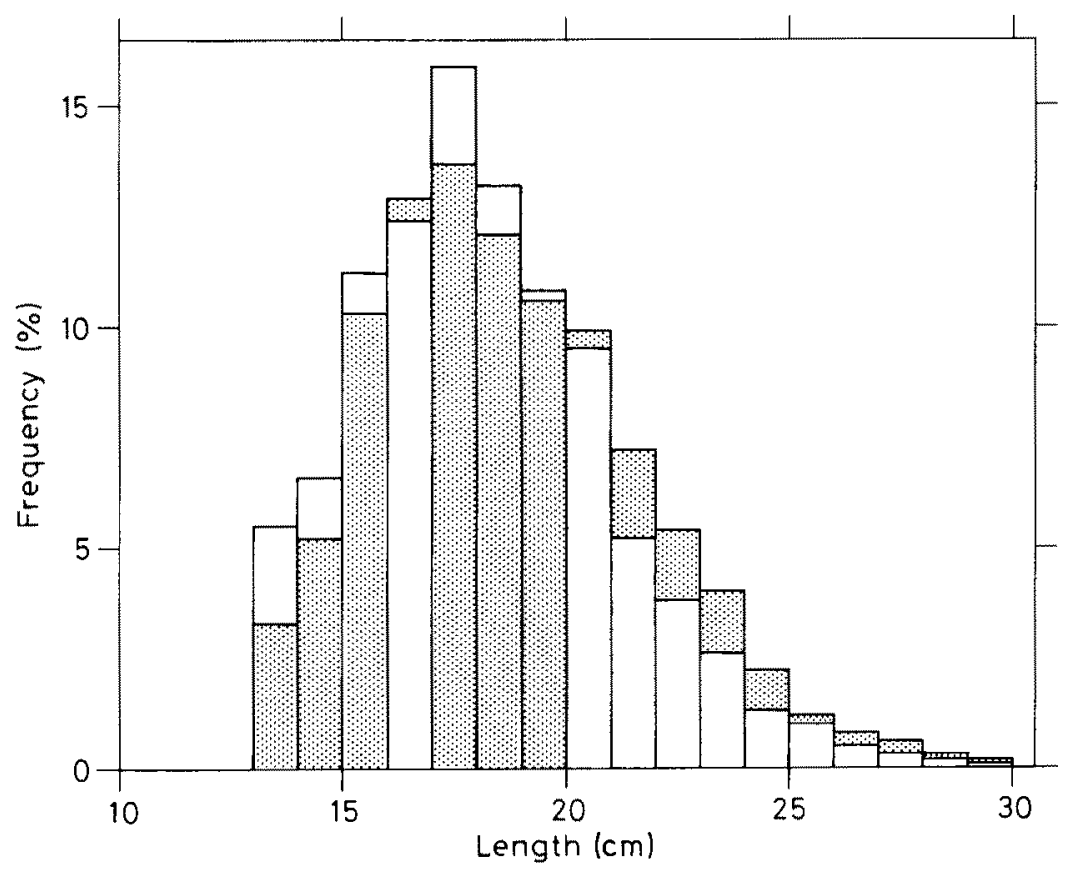

Fig. 4. Limanda limanda: June 1980. Epidermal papilloma. Relative frequencies of dab in Areas A (shaded) and $C$ (see Fig. 1) in relation to length classes found to be afflicted $\left(n_{A}=5523, n_{C}=\right.$ 14 299)

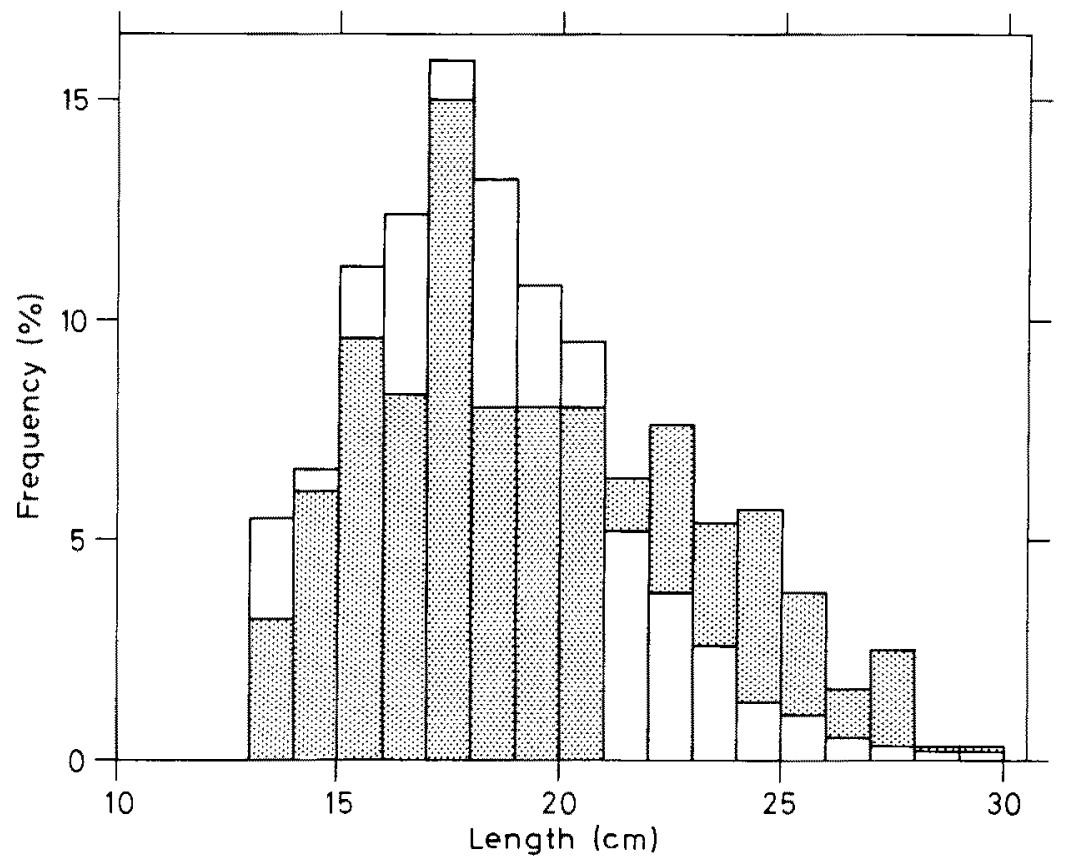

Fig. 5. Limanda limanda: June 1980. Epidermal papilloma. Relative frequencies of dab in Areas B (shaded) and $C$ (see Fig. 1) in relation to length classes found to be afflicted $\left(n_{B}=314, n_{C}=14299\right.$ ) 


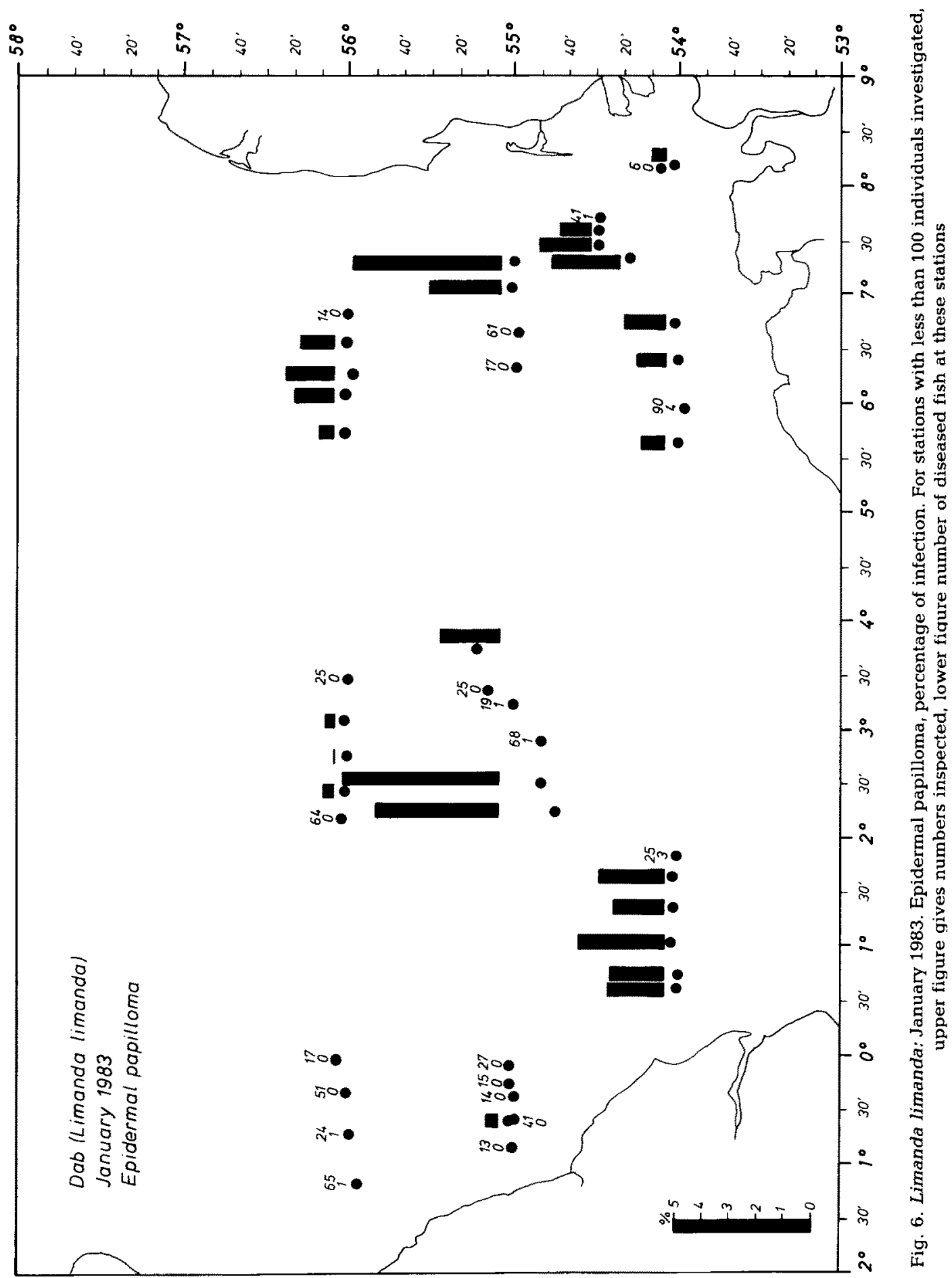




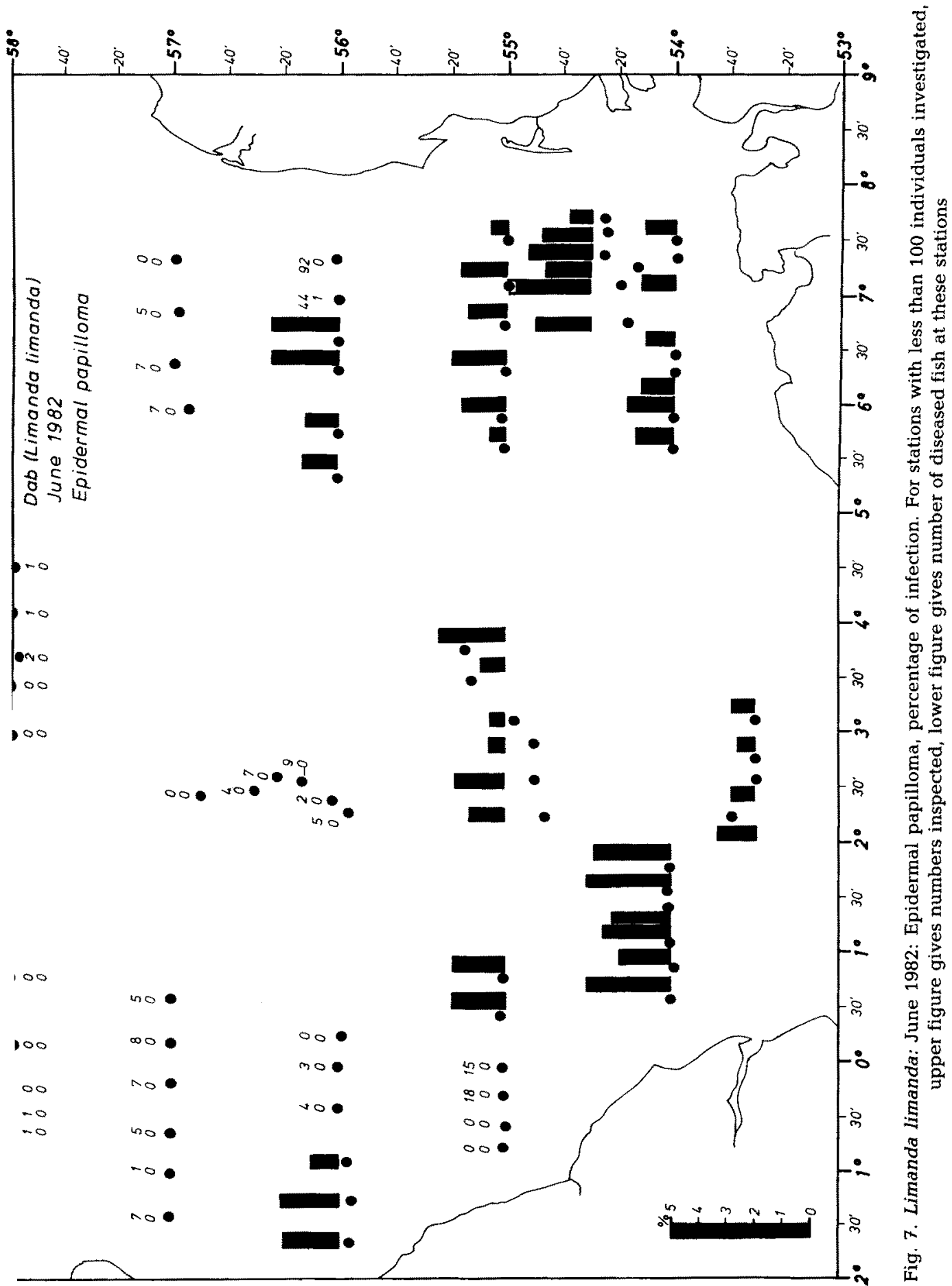


diseased specimens were caught in the central part of the German Bight, off the Humber estuary and off the River Tyne.

Since the first systematic epidemiological investigation in the North Sea in the late 1970 's, information is now available on the occurrence of epidermal papilloma in dab also from other areas. Wootten et al. (1982) demonstrated the occurrence of this disease in dab from Scottish coastal waters in relatively high frequencies. It was also found during a single-cruise survey in the southern Irish Sea. Average infection during this cruise was $1.1 \%$ (Bucke et al., 1983a).

On the other hand, McArdle et al. (1982) and Bucke et al. (1983b) failed to demonstrate the presence of this disease in dab on the east coast of Ireland and from the Thames estuary. It was present in Danish waters up to the Kategatt area (Moller, 1981) and in Dutch, Belgian and French coastal waters (P. van Banning et al,; pers. comm.). From these findings it can be concluded that in the southern North Sea and in certain coastal areas of the northern North Sea percentages of dab afflicted with epidermal papilloma appear to be similar to those observed during our cruises. In contrast, Möller (1981) found exceptionally low infection rates during his investigation on the occurrence of this disease in German and Danish coastal waters. In context with our studies investigations have been made on the seasonal fluctuations of diseases of dab in certain areas within the German Bight (Wolthaus, 1984). His results reveal that the relative frequencies of dab afflicted with epidermal papilloma undergo marked seasonal fluctuations, with maxima in April and lowest infection rates in August. As Möller surveyed the area in August 1980, he covered a period of minimum infection rates; his conclusions are therefore of limited value.

Regarding the occurrence of the disease in dab of the German Bight, the statement by Dethlefsen \& Watermann (1980) is still valid. The centre of the German Bight features increased frequencies of dab afflicted with papilloma. This finding is further strengthened by results of Wolthaus (1984). During a period of 20 months, infection rates of dab with epidermal papilloma in the dumping area were consistently higher than in reference areas. This is the area used for dumping of wastes from titaniumdioxide production. On a wider geographic scale, further disease hot spots can be realized. One is located in areas in the relative vicinity of the Humber estuary close to the Dogger Bank. Other locations near the British east coast off the Tyne estuary are also characterized by increased frequencies of dab with epidermal papilloma.

\section{Biological factors}

Some of the biological factors to be considered as being possibly involved in triggering the outbreak of fish diseases are: condition factor (expressing the nutritional status of the fish), food, population density (influencing the spread of a communicable fish disease) as well as the role of fisheries. Below, some information is given on these factors in relation to the occurrence and abundance of epidermal papilloma in dab.

\section{Condition factor}

In general, diseased fishes show lower condition factors than fishes without obvious indications of disease; this has been demonstrated for plaice infected by lymphocystis by Mann (1970) and for ulcerated dab by Möller (1981). There is some indication that a 
negative correlation might exist between the prevalence of diseased dab and a low condition factor if infection rate and condition of healthy specimens are compared at corresponding stations (Möller, 1981). Wedemeyer (1970) draws attention to the importance of the nutritional state of the host and to the interaction between nutritional deficiencies and infectious agents. According to Scrimshaw (1966), synergistic and antagonistic interactions of nutrition and infection exist.

In October 1981, condition factors of healthy females were taken from dab from the Dogger Bank and the German Bight area for comparative purposes. In general, condition factors of females from the Dogger Bank were lower than those recorded for female dabs from the German Bight area. In the centre of the German Bight elevated condition factors of dab were found. In our data, no correlation was detectable between the prevalence of epidermal papilloma and condition of dab when these correlations were calculated for the German Bight and the Dogger Bank separately.

\section{Stomach content}

According to Lee (1972), dab on the Dogger Bank might suffer from starvation, since the rich biomass available is low in nutrient value. Possibly, this means that the major food sources of dab in that area are echinoderms. We investigated stomach contents of dab in May 1983 from stations in the southern North Sea. Thirty fish per station were investigated and major food sources were recorded. The proportion of dab feeding on echinoderms was variable and no consistent picture could be obtained for the area covered. Dab from stations of the Dogger Bank area did not feed predominantly on echinoderms. Dab feed on benthos organisms available in their habitat (Kühl, 1963), Regional differences in stomach-content of dab would therefore reflect differences in abundance of benthos. According to Ursin (1960), the number of echinoderm specimens per unit of area was particularly low on the Dogger Bank. Petersen (1977) found the highest total macrobenthic biomass on the Dogger Bank as compared to that of other North Sea areas. Similarly, Rachor (1982) showed that the total biomass of macrobenthos on the Dogger Bank was higher than that of other areas. Neither lack of food nor predominance of food organisms low in nutrient value would therefore explain the lower condition factors of dab from this area.

\section{Population density}

High population density can facilitate the transmission of communicable diseases and may increase the susceptibility of fish to disease due to stress caused by crowding (Sindermann, 1979). We therefore investigated whether correlations existed between infection rates and the population density of dab in our data. Again two typical examples are given, one from June 1982 and one from January 1983 (Fig. 8). In general, the population density, expressed as numbers of fish caught per $30 \mathrm{~min}$ of trawling, was higher during the summer cruise than that measured during the winter trawling. During summer, high population density was encountered at certain stations within the German Bight, the Dogger Bank and off the British coast. This implies that a correlation between prevalences of fishes afflicted with epidermal papilloma and population density might exist. If correlations were calculated between the two factors for the respective cruises the results were negative. 

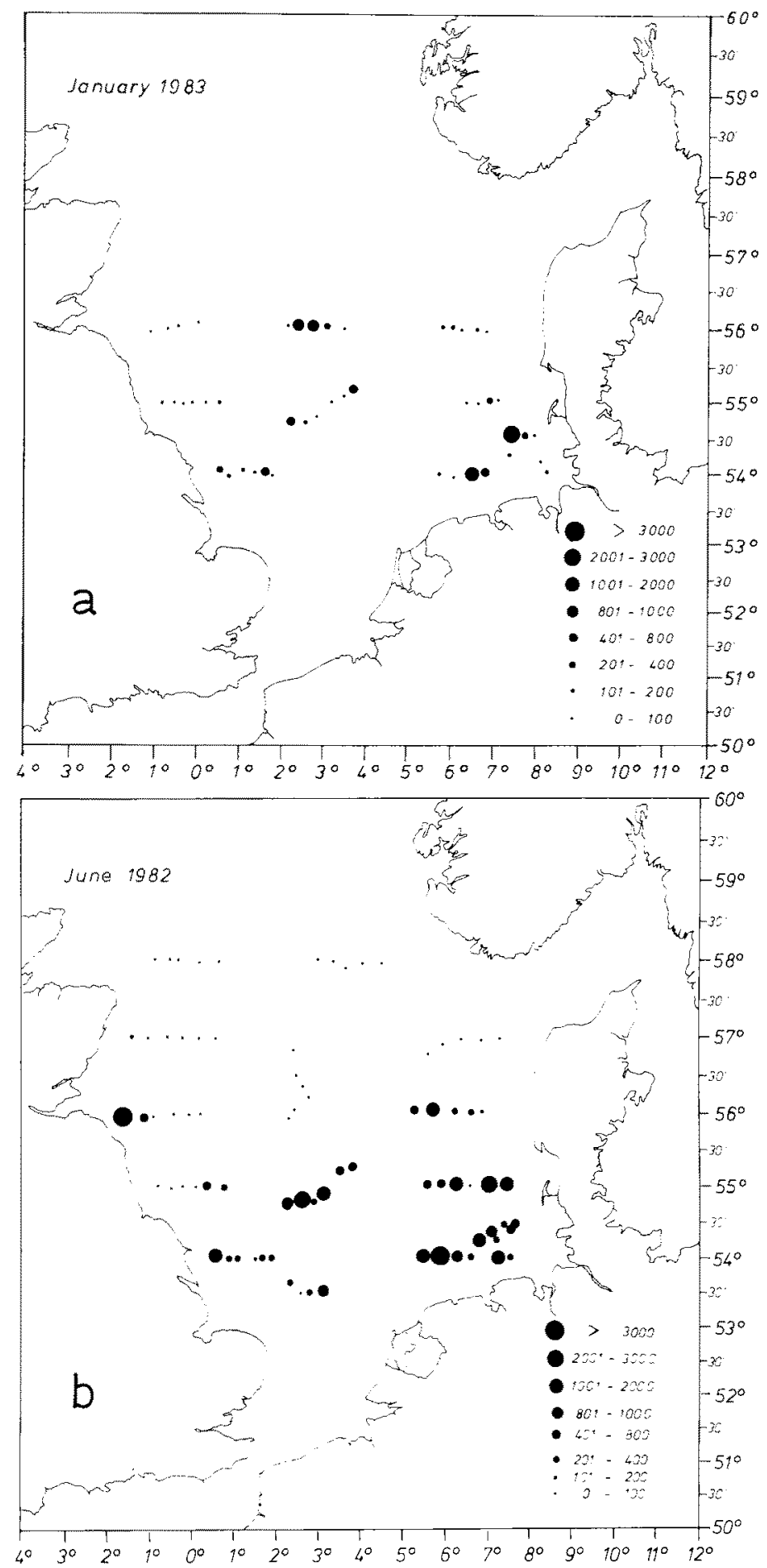

Fig. 8. Limanda limanda: June 1982 and January 1983. Population density expressed as numbers of individuals caught per 30 min of trawling 


\section{Net injuries}

Fishing pressure is supposed to be one significant stress on exploited fish populations. One of the assumptions heard in this context is that in areas with high fishing pressure infection rates of fishes might be higher due to net injuries. Danish investigators suggested that a correlation exists between fishing activities and frequencies of ulcers in cod from Baltic coastal regions (Miljö-Projekter, 1981). During our investigations we often encountered net damage of dab at different stages of healing. We investigated the frequency of these phenomena and recorded whether fish with healed net injuries were otherwise healthy or diseased. Table 3 lists results for January 1983.

Table 3. Limanda limanda. Diseases in dab with and without healed net injuries (January 1983); $\mathrm{n}=$ number of individuals examined

\begin{tabular}{|ccccc|}
\hline $\mathrm{n}$ & $\begin{array}{c}\text { Epidermal } \\
\text { papilloma (\%) }\end{array}$ & $\begin{array}{c}\text { Lymphocystis } \\
(\%)\end{array}$ & $\begin{array}{c}\text { Ulcerations (\%) } \\
\text { acute }\end{array}$ & \\
\hline $\begin{array}{c}\text { Fish with healed } \\
54\end{array}$ \\
$\begin{array}{c}\text { Fish without net damages } \\
7280\end{array}$ & 1.85 & 5.56 & 0.0 & 3.7 \\
\hline
\end{tabular}

Altogether 54 fish with healed net injuries and 7280 fish without net injuries were investigated. Infection rates for epidermal papilloma and lymphocystis and different stages of ulcerations were similar. Only for healed ulcerations were higher prevalences found on fish with healed net injuries. This might be due to the fact that the healing of wounds from net injuries and that of ulcers is similar. The two symptoms might therefore be confused.

When linear correlations are calculated between the relative frequency of netinjured fishes and the relative frequencies of diseased fishes at stations fished in January 1983, these correlations were positive for the three diseases mentioned. This might indicate that at certain periods of the year a link exists between fishing pressure and relative frequencies of diseased dab.

The assumption that fishing pressure plays a role in triggering disease of dab needs to be substantiated by further investigations. Considering net injuries as a possible factor contributing to the outbreak of disease it should be mentioned that regeneration of wound healing processes in fish might be retarded in the presence of organochlorines and heavy metals (Weis \& Weis, 1976).

\section{Chemical factors of relevance for the distribution of dab afflicted with epidermal papilloma}

Since 1969, the centre of the German Bight has been used for the dumping of annually $750000 \mathrm{t}$ of $12 \%$ acid iron wastes from titaniumdioxide production. Iron accompanied by a variety of heavy metals with carcinogenic potential - such as chromium, manganese and titanium - prevails in increased concentrations in the centre and vicinity of the dumping area (Weichart, 1975). Concentrations of ca $1 \mathrm{mg} \mathrm{Fe} \mathrm{l}^{-1}$ 
persist for considerable periods of time in the dumping area. Often Fe concentrations in bottom near waters exceed those measurable at the surface (Schmidt, 1980; own data, Deutsches Hydrographisches Institut, 1983). Increased levels of heavy metals due to the dumping were also analyzed in sediments of the dumping area as shown by results of three independent studies (Dominik et al., 1978; Irion, 1982; Haase, 1983). We investigated whether some of these heavy metals might be retrieved from dab tissues.

\section{Iron in epidermis}

Iron staining with Prussian blue of paraffin sections of the epidermis of dab revealed the presence of particulate iron in mucous cells in the neighbourhood of papillomas. This could be demonstrated for fish from waste dumping areas (wastes from titaniumdioxide production and from sewage sludge) in the inner German Bight. Iron particles were visible in mature mucous cells near the surface in mucous granules. In some cases, iron was also present in the intermediate layers of the epidermis. In histological sections of fish from other areas of the German Bight (from stations about 80 nautical miles west of the Island of Sylt and north of the East Frisian Islands), iron was detected only in singular cases in the epidermis of dab in the above-mentioned distribution patterns, i.e. in mucous cells. This was also true in sections from fish from the Dogger Bank area, and from stations off the British coast where iron was found only in macrophages inside the stroma underlying epidermal papilloma.

\section{Chromium in liver and epidermal tissue}

In January 1981, liver and tissue (dorsal fin) samples were taken from dab caught in the German Bight and analyzed for chromium (Fig. 9). At the stations in the Elbe estuary, chromium values in livers of dab were elevated and there were slightly increased chromium concentrations in livers of dab from the vicinity of the dumping area for titaniumdioxide wastes.

Highest chromium concentrations in dorsal fins of dab are carried by individuals in the vicinity of the dumping area. Increased values were still detected in fish from regions northeast and southwest from this location. Two ways of uptake of chromium are suggested: (1) Uptake through food resulting in high concentrations in fishes in the Elbe estuary; high chromium contents were demonstrated for ophiurids from this area. (2) Uptake through absorption by external tissues resulting in increased epidermal chromium in dab from the titaniumdioxide wastes dumping area.

The occurrence of particulate iron in certain epidermis cells of dab from the dumping area, as demonstrated by histochemical methods, shows that iron accompanied by the carcinogenic chromium may intrude into sensitive target cells. Lehtinen \& Klingstedt (1983) detected iron, titanium and copper in mucous cells of gill epithelium of the experimental fish after exposure to wastes from titaniumdioxide production. Karjala (1980, cited after Pickaver, 1982) found elevated concentrations of copper, cadmium, lead and zinc in gills of flounders from an area where wastes from titaniumdioxide production are dumped. Temmink et al. (1983) demonstrated that chromium exposure induced gill hyperplasia in trout. McDermott et al. (1976) analyzed higher chromium concentrations in livers and kidneys of Dover sole with fin rot as compared to healthy specimens. 

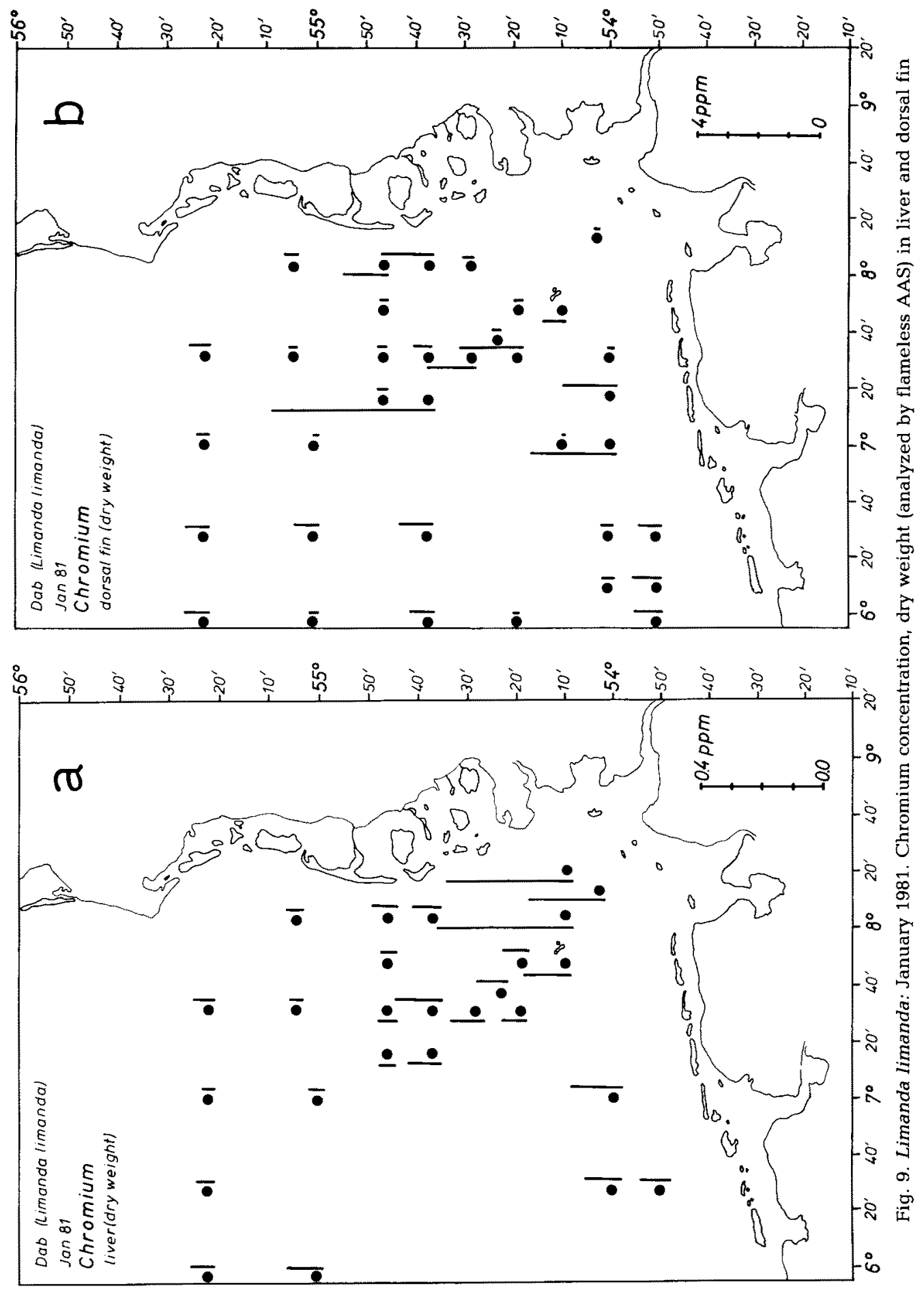


\section{CONCLUSIONS}

Dab Limanda limanda and cod Gadus morhua are the species most frequently afflicted with various diseases which sometimes occur in epizootic proportions in the North Sea (Möller, 1979; Dethlefsen, 1980; Möller, 1981; Watermann et al., 1982). The abundance of both species has significantly increased in the southern North Sea over the last 20 yr (Cushing, 1983; Tiews, 1983). Reasons for the recent increase in abundance of dab and cod are unknown. Cushing (1983) draws attention to the existence of long-term periodicities in production cycles in the North Sea. Due to the increase in numbers of fishes, the host-agent relations for these two species must have changed during the last 20 yr causing an imbalance to the advantage of the agents.

For the same period, significant changes in water quality are documented. For example, the concentrations of nutrients in German coastal waters have increased (Gillbricht, 1981). Low dissolved oxygen situations recur in bottom-near waters in German, Danish and Swedish coastal waters (Lindahl \& Hernroth, 1981; Dethlefsen \& von Westernhagen, 1983; Dyer et al., 1983; Rachor \& Albrecht, 1983).

A recent increase in heavy metals in sediments has been documented by Förstner \& Patchineelam (1981). The parallelism of changes in stocks and in water quality make it almost impossible to define the role of the two factors in their contribution to the outbreak of the diseases discussed in this review. These difficulties are aggravated by the high variability of our data (Dethlefsen et al., 1984). The variability is significantly influenced by the seasonality of disease frequencies. There is also a remarkable haul-tohaul and station-to-station variability which is, to a certain degree, superimposed by individual differences in the accuracy of different investigators. The situation is further complicated by the fact that the area under survey is far from being homogenous in hydrographical, topographical or biological terms. Our assumptions concerning pollutant gradients are often over-simplifications. While concentrations of certain heavy metals in seawater and organisms are high in onshore waters and decrease with increasing distance from the coast (Harms, 1975; Schmidt, 1980), certain heavy metals, e.g. cadmium, do not follow this pattern, being more evenly distributed than others (Schmidt, 1980). In regard to arsenic in fillet of plaice, increased concentrations were found in fish from offshore regions in the German Bight (Andersen, 1979). Certain organochlorine residues in livers of cod from offshore regions were much higher than in onshore fish (Kerkhoff et al., 1982).

Concentration gradients of oil and related substances display unorthodox patterns due to location of production sites in the central northern North Sea (Gunkel et al., 1980). Furthermore, figures for prevalence of fish diseases do not indicate the incidence at which a disease occurs in a fish population (Wootten et al, 1982). A low prevalence might result from mortalities due to the disease, and high prevalences might occur for very short periods, e.g. immediately after pollution impact.

Despite these uncertainties, our data suggest that links might exist between increased prevalence of diseased dab and substances discharged with wastes from titaniumdioxide production. It is possible that heavy metals, including chromium, are involved in aggravating prevalences of epidermal papilloma in dab. The Dogger Bank area features exceptionally high rates of disease in dab, and it is one with exceptional combinations of high heavy metal concentration (Baker, 1977) and high concentrations 
of PCB's (Gaul \& Ziebart, 1983). High frequencies of diseased dab at stations off the British coast near highly industrialized areas possibly reflect the degree of contamination of these coastal stretches. In most attempts at documenting a relation between fish diseases and pollution, relatively short distances were covered between pollution hot spots and reference areas (Möller, 1981; McArdle et al., 1982; Bucke et al., 1983a, b).

Areas characterized by high frequencies of diseased dab coincide with long-range transport routes of persistent pollutants (see Kautsky [1977] for long-range transport of radioactive material). This could lead to the hypothesis that large-scale occurrence of fish diseases reflects long-range transport of pollutants.

From the information at hand, the following conclusions may be drawn: (1) In the North Sea, cod and dab are the fish species most frequently afflicted with externally visible lesions. While lymphocystis, ulcerations and epidermal papillomas are the most frequently occurring external lesions in dab, pseudobranchial tumours and ulcerations are most frequently observed in cod. (2) Starting in the German Bight, a northwestern transect up to $60^{\circ} \mathrm{N}$ and the Humber estuary, and from there a northeastern transect to $60^{\circ} \mathrm{N}$ and areas off the British coast, are characterized by increased frequencies of diseased dab. (3) For epidermal papillomas of dab in the German Bight the following statements can be made: (a) There is a coincidence of elevated tumour rates and elevated concentrations of heavy metals in water, sediments and fish tissue in the dumping area for wastes of titaniumdioxide production and its vicinity. (b) Heavy metals with carcinogenic potential were shown to be present in target tissues of fish from the same area. (c) Involvement of these substances in tumour genesis is likely. (d) Density dependency, role of nutritional status, and the influence of fisheries on the diseases remain uncertain.

The occurrence of increased prevalences of diseases of North Sea fishes should be interpreted as evidence for an increasing impact on the local marine ecosystem. In view of the uncertainty concerning the causes of the changes observed, careful attention must be paid to marine pollution management.

\section{LITERATURE CITED}

Andersen, A., 1979. Trace elements in plaice from the North Sea, 1979. - B1. Stat. Levnedsmiddelinst. $67,1-31$.

Baker, C. W., 1977. Mercury in surface of seas around the United Kingdom. - Nature, Lond. 270, $230-232$.

Bucke, D., Feist, S. W. \& Rolfe, M. S., 1983a. The field assessment of effects of dumping wastes at sea. A study of epidermal lesions and abnormalities of fish in the Liverpool Bay area of the northeast Irish Sea. - Fish. Res. tech. Rep. (In press).

Bucke, D., Norton, M. \& Rolfe, M. S., 1983b. The field assessment of effects of dumping wastes at sea. II. A study of epidermal lesions and abnormalities of fish in the outer Thames Estuary.Fish. Res. tech. Rep. 72, 1-16.

Bückmann, A., 1952. Infektionen mit Glugea stephani und Vibrio anguillarum bei Schollen (Pleuronectes platessa L.). - Kurze Mitt. fischbiol. Abt. Max-Planck-Inst. Meeresbiol. Wilhelmsh. $1,1-7$.

Cochran, W. G., 1954. Some methods for strengthening the common $\chi^{2}$ tests. - Biometrics 10 , 417-451.

Cushing, D. H., 1983. Sources of variability in the North Sea ecosystem. In: North Sea dynamics. Ed. by J. Sündermann \& W. Lenz. Springer, Berlin, 499-516.

Dethlefsen, V., 1980. Observations on fish diseases in the German Bight and their possible relation to pollution. - Rapp. P.-v. Réun. Cons. int. Explor. Mer 179, 110-117. 
Dethlefsen, V. \& Watermann, B., 1980. Epidermal papilloma of North Sea dab (Limanda limanda); histology, epidemiology and relation to dumping of wastes from $\mathrm{TiO}_{2}$ industry. - ICES Special Meeting on Diseases of Commercially Important Marine Fish and Shellfish. 8.

Dethlefsen, V., Watermann, B. \& Hoppenheit, M., 1984. Sources of variance in data from fish disease surveys. - ArchFisch. Wiss. 34, 2/3, 155-173.

Dethlefsen, $\mathrm{V}$. \& Westernhagen, H. von, 1983. Oxygen deficiency and effects on bottom fauna in the eastern German Bight 1982. - Meeresforschung 30, 42-53.

Deutsches Hydrographisches Institut, 1983. Überwachung des Meeres. Bericht für das Jahr 1981. Teil II: Daten. Deutsches Hydrogr. Inst., Hamburg, $121 \mathrm{pp}$.

Dominik, J., Förstner, U, Mangini, A. \& Reineck, H.-E., $1978 .{ }^{210} \mathrm{pb}$ and ${ }^{137} \mathrm{Cd}$ chronology of heavy metal pollution in a sediment core from the German Bight (North Sea), - Senckenberg. marit. 10, 213-227.

Duncan, A. J., 1974. Quality control and industrial statistics. Irwin, Homewood, IIl, 1047 pp.

Dyer, M. F., Pope, J. G., Fry, P. D., Law, R. J. \& Portmann, J. E., 1983. Changes in fish and benthos catches off the Danish coast in September 1981. - J. mar. biol. Ass. U. K. 63, 767-775.

Egidius, E. C., Johannessen, J. V. \& Lange, E., 1981. Pseudobranchial tumours in Atlantic cod, Gadus morhua L., from the Barents Sea. - J. Fish Dis. 4, 527-532.

Förstner, U. \& Patchineelam, S. R., 1981. Chemical associations of heavy metals in marine deposits with special reference to pollution in the German North Sea. - Rapp. P.-v. Réun. Cons. int. Explor. Mer 181, 49-58.

Gaul, H. \& Ziebarth, U., 1983. Method for the analysis of lipophilic compounds in water and results about the distribution of different organochlorine compounds in the North Sea. - Dt. hydrogr. Z. $36,191-212$.

Gillbricht, M., 1981. Hydrographie, Nährstoffe und Phytoplankton bei Helgoland. - Jber. Biol, Anst. Helgoland 1980, 23-26.

Gunkel, W., Gassmann, G., Oppenheimer, C. H. \& Dundas, I., 1980. Preliminary results of baseline studies of hydrocarbons and bacteria in the North Sea. In: Ponencias del simposio internacional en: Resistencia a los antibioticos y microbiologia marina. Santiago de Compostela (España), 223-247.

Haase, G. M., 1983. Sedimentological and geochemical investigations in the dumping area for wastes of titaniumdioxide production in the Helgoland Bight. - Veröff. Inst. Meeresforsch. Bremerh. 19, 133-144.

Harms, U., 1975. The levels of heavy metals (Mn, Fe, $\mathrm{Co}, \mathrm{Ni}, \mathrm{Cu}, \mathrm{Zn}, \mathrm{Cd}, \mathrm{Pb}, \mathrm{Hg}$ ) in fish from onshore and offshore waters of the German Bight. - Z. Lebensmittelunters.-Forsch. 157, 125-132.

Irion, G., 1982. Schwermetallgehalte in der Deutschen Bucht. - Bild der Wissenschaft 7, 47.

Johnstone, J., 1913. Diseased conditions of fishes. - Proc. Trans. Liverpool biol. Soc. 27, 196-218.

Johnstone, J., 1925. Malignant tumours in fishes. - Proc. Trans. Liverpool biol. Soc. 39, 169-200.

Kamp, G. van de, 1977. Vertebral deformities of herring around the British Isles and their usefulness for a pollution monitoring programme. - C.M./ICES E 5 .

Kautsky, H., 1977. Strömungen in der Nordsee. - Umschau 77, 672-673.

Kerkhoff, M. Otte, P. \& Boer, J. de, 1982. Chlordane components in the North Sea, their origin and pathway. - C.M./ICES E 57 .

Koops, H. \& Mann, H., 1969. Die Blumenkohlkrankheit der Aale. Vorkommen der Verbreitung der Krankheit. - Arch. FischWiss. (Beih.) 20, 5-15.

Koops, H., Mann, H., Pfitzner, I., Schmidt, O. J. \& Schubert, G., 1970. The cauliflower disease of eels. In: A symposium on diseases of fishes and shellfishes. Ed. by S. F. Snieszko. Am. Fish. Soc., Washington, 291-295. (Spec. Publ. Am. Fish. Soc. 5).

Kühl, H., 1963. Uber die Nahrung der Scharbe (Limanda limanda L.), - Arch. FischWiss. 14, 8-17.

Lamp, F., 1973. Das Wanderverhalten des Kabeljau der Deutschen Bucht. - Arch. FischWiss. 24, $155-169$.

Lange, E., 1973. Carcinoid-like tumours in the pseudobranch of Gadus morhua. - Comp. Biochem. Physiol. 45 A, 477-481.

Lange, E. \& Johannessen, J. V., 1977. Histochemical and ultrastructural studies of chemodectomalike tumours in the cod (Gadus morhua). - Lab. Invest. 37, 96.

Lee, C. K. C., 1972. The biology and population dynamics of the common dab Limanda limanda (L.) in the North Sea. - Ph. D. thesis, Univ, of East Anglia, 105 pp. 
Lehtinen, K.-J. \& Klingstedt, G., 1983. X-ray microanalysis in the scanning electron microscope on fish gills affected by acidic, heavy metal containing industrial effluents. - Aquat. Toxicol. 3, 93-102.

Lindahl, I. \& Hernroth, L., 1981. The coastal waters of western Sweden - an ecosystem off balance? C.M./ICES $L 35$.

Mann, H, 1970. Uber den Befall der Plattfische der Nordsee mit Lymphocystis. - Ber. dt. wiss. Kommn Meeresforsch. 21, 219-223.

McArdle, J., Dunne, T., Parker M., Maryn, C. \& Rafferty, D., 1982. A survey of diseases of marine flatfish from the east coast of Ireland in 1981. - C.M./ICES E 47.

McCain, B. B., Grolund, W. D., Myers, M. S. \& Wellings, S. R., 1979. Tumours and microbial diseases of marine fishes in Alaskan waters. - J. Fish Dis. 2, 111-130.

McDermott, D. J., Alexander, G. V., Young, D. R. \& Mearns, A. J., 1976. Metal contamination of flatfish around a large submarine outfall. $-J$. Wat. Pollut. Control Fed. 48, 1913-1918.

Mcintyre, A. D. \& Pearce, J. B. (Eds), 1980. Biological effects of marine pollution and the problems of monitoring. - Rapp. P.-v. Réun. Cons. int. Explor. Mer 179, 1-346.

Miljö-Projekter, 1981. Fiskepatologiske or mikrobiologiske undersogelser i kystnaert, marint miljo. Miljoministeriet miljostyrelsen, Kobenhavn, $180 \mathrm{pp}$.

Möller, H., 1979. Geographical distribution of fish diseases in the NE Atlantic. - Meeresforschung 27, $217-235$.

Möller, H, 1981. Fish diseases in German and Danish coastal waters in Summer 1980, - Meeresforschung 29, 1-16.

Morrison, C. M., Appy, R. G., Shum, G., Annand, G. \& Odense, P., 1979. Histology and the incidence of pseudobranch tumours in Atlantic cod (Gadus morhua) in Halifax Harbour. - C.M./ICES E 31 .

Munro, A. L. S., 1983. Are communicable diseases a significant source of mortality in exploited marine fish populations? - C.M./ICES Gen 5.

Peters, G., 1975. Seasonal fluctuations in the incidence of epidermal papilloma of the European eel Anguilla anguilla L. - J. Fish Biol. 7, 415-422.

Peters, N., Peters, G. \& Bresching, G., 1972. Redifferenzierung und Wachstumshemmung von epidermalen Tumoren des europäischen Aals unter Einwirkung von Chininsulfat. - Arch. FischWiss. 23, 47-63.

Petersen, G. H., 1977. The density, biomass and origin of the bivalves of the central North Sea. Meddr Danm. Fisk.-og Havunders. 7, 221-273.

Peyron, A. \& Thomas, L., 1929. Contribution à l'étude des tumeurs du rêvetement branchial chez les poissons. - Bull. Ass. fr. Etude Cancer 18, 825-827.

Pickaver, A. H., 1982. Titanium dioxide waste dumping at sea. Time to call a halt. - Mar. Pollut. Bull. 13, 375-379.

Rachor, E., 1982. Biomass distribution and production estimates of macro-endofauna in the North Sea. - C.M./ICES $L 2$.

Rachor, E. \& Albrecht, H., 1983. Sauerstoff-Mangel im Bodenwasser der Deutschen Bucht. - Veröff. Inst. Meeresforsch. Bremerh. 19, 209-227.

Russel, F. S., 1973. A summary of the observations on the occurrence of planktonic stages of fish off Plymouth 1924-1972. - J. mar. biol. Ass. U. K. 53, 347-356.

Schäperclaus, W., 1979. Fischkrankheiten. Akademie-Verl, Berlin, 1089 pp.

Schmidt, D., 1980. Comparison of trace heavy-metal levels from monitoring in the German Bight and the southwestern Baltic Sea. - Helgoländer Meeresunters. 33, 576-586.

Scrimshaw, N. S., 1966. Synergistic and antagonistic interactions of nutrition and infection. - Fedn Proc. Fedn Am. Socs exp. Biol. 25, 1679-1681.

Shelton, R. G. J. \& Wilson, K. W., 1973. On the occurrence of lymphocystis, with notes on other pathological conditions, in the flatfish stocks of the north-east Irish Sea. - Aquaculture 2, $395-410$.

Sindermann, C. J., 1979. Pollution-associated diseases and abnormalities of fish and shellfish: a review. - Fish. Bull. U. S. 76, 717-749.

Sindermann, C. J., 1983. An examination of some relationships between pollution and disease. Rapp. P.-v. Réun. Cons. int. Explor. Mer 182, 37-43.

Sindermann, C. J., Bang, F. B., Christensen, N. O., Dethlefsen, V., Harshbarger, J. C., Mitchell, J. R. 
\& Mulcahy, M. F., 1980. The role and value of pathobiology in pollution effects monitoring programs. - Rapp. P.-v. Réun. Cons. int. Explor. Mer 179, 135-151.

Stich, H. F., Acton, A. B. \& Forrester, C. R., 1976. Fish tumours and sublethal effects of pollutants. -J. Fish. Res. Bd Can. 33, 1993-2001.

Temmink, J. H. M., Bouwmeister, P. J., Jong, P. de \& Berg, J. H. J. van den, 1983. An ultrastructural study of chromate-induced hyperplasia in the gill of rainbow trout (Salmo gairdneri). - Aquat. Toxicol. 4, 165-180.

Tiews, K., 1983. Uber die Veränderungen im Auftreten von Fischen und Krebsen im Beifang der deutschen Garnelenfischerei während der Jahre 1954-1981. - Arch. FischWiss. 34, 1-156.

Ursin, E., 1960. A quantitative investigation of the echinoderm fauna of the central North Sea. Meddr Danm. Fisk.- og Havunders. (N. S.) 2 (24), 1-204.

Watermann, B., 1979. Zur Histologie und Genese von Geschwüren und Papillomen von Klieschen (Limanda limanda L.) der Deutschen Bucht. Dipl.-Arb., Univ. Hamburg, 44 pp.

Watermann, B., 1982. An unidentified cell type associated with an inflammatory condition of the subcutaneous connective tissue in dab, Limanda limanda L. Short communication. - J. Fish Dis. $5,257-261$.

Watermann, B. \& Dethlefsen, V., 1982. Histology of pseudobranchial tumours in Atlantic cod (Gadus morhua) from the North Sea and the Baltic Sea. - Helgoländer Meeresunters. 35, $231-242$.

Watermann, B., Dethlefsen, V. \& Hoppenheit, M., 1982. Epidemiology of pseudobranchial tumours in Atlantic cod (Gadus morhua) from the North Sea and the Baltic Sea. - Helgoländer Meeresun* ters. 35, 231-242.

Wedemeyer, G., 1970. The role of stress in the disease resistance of fishes. Am. Fish. Soc., Washington, 30-35. (Spec. Publ. Am. Fish. Soc. 5).

Weichart, G., 1975. Untersuchungen über die Fe-Konzentration im Wasser der Deutschen Bucht im Zusammenhang mit dem Einbringen von Abwässern aus der Titandioxid-Produktion. - Dt. hydrogr. Z. 28, 49-61.

Weis, J. S. \& Weis, P, 1976. Effects of heavy metals on fin regeneration in the killifish, Fundulus heteroclitus. - Bull, environ. Contam. Toxicol. 16, 197-202.

Wolthaus, B.-G., 1984. Seasonal changes in frequency of diseases in dab Limanda limanda from the southern North Sea. - Helgoländer Meeresunters. 37, 375-387.

Wootten, R., McVicar, A. H. \& Smith, J. W., 1982. Some disease conditions of fish in Scottish waters. - C.M./ICES E 46 .

Wunder, W., 1971. MiBbildungen beim Kabeljau (Gadus morhua) verursacht durch Wirbelsäulenverkürzung. - Helgoländer wiss. Meeresunters. 22, 201-212. 